\title{
Numerical Simulation and Analysis of Sewage Heat Utilization with Sewage Heat Exchanger
}

\author{
Changming Zhou ${ }^{1, a}$, Hong KAN ${ }^{1, b}$ \\ ${ }^{1}$ College of Mechanical Engineering; Tianjin University of Science\&Technology;
}

Tianjin; 300222; China

Keywords: Heat Pipe; Recycling; Waste Water Heat Utilization; Numerical Simulation

\begin{abstract}
Recycling of waste heat with heat pipe is one recognized effective approach to save energy and prevent global warming. Energy saving and efficiency enhancement of heat pipe exchanger for residual heat recycling, particularly the conventional heat pipe (CHP), two-phase closed thermosyphon (TPCT) and oscillating heat pipe (OHP) are summarized in this paper. The efficiency parameters of CHP, TPCT and OHP are analyzed. Optimal solution for design of heat pipe exchanger used in heat recycling system is provided.
\end{abstract}

\section{Introduction}

Waste heat recycling with heat pipe is one excellent approach to save energy and prevent global warming. Heat pipe exchanger, as one efficient gas-gas heat recycling device, is widely applied to business and industrial production. It becomes the best choice because there is no cross leakage between waste gas and supply air. Heat pipe exchanger is characterized with many advantages, like high heat exchange efficiency, compact structure, no movable part, light weight, relatively economical, small pressure drop at the air side, completely separation of the thermal fluid and cold fluid, safe and reliable. This exchanger is widely applied to waste heat recycling system of various sectors (energy engineering, chemical engineering and metallurgical engineering). One important function of heat pipe exchanger is to recycle the heat from the waste heat of boiler. Fig. 1 shows the comparison between conventional boiler and the boiler with heat pipe exchanger. In conventional boiler (Fig. 1a), the waste gas is directly emitted to the air, which not only wastes the energy but gets the environment polluted. Heat pipe exchanger (Fig. 1b) can help not only save energy but protect the environment. In any case, heat recycling with heat pipe is very necessary, particularly for study on energy saving and environmental effect.

\section{Heat Recycling with Heat Pipe}

Recently, research people have been increasingly interested in heat recycling with heat pipe. There are also papers starting to analyze the application, design, structure and thermal performance. Noie-Baghban and Majideian[2] have introduced the conventional heat pipe for water heat recycling in the operation room, which is designed for low temperature source $\left(15 \sim 55^{\circ} \mathrm{C}\right)$. The research shows that the efficiency of the conventional heat pipe is 0.16 . although this value depends on the diameter of heat pipe and fin gap, it is very small simply because it is designed for low temperature conditions. Abd El-Baky and Mohamed[3] have verified the thermal transmission and change of new air temperature by testing the mass flow rate between return air and fresh air (1, 1.5 and 2.3) in order to cool the fresh air and apply the conventional heat pipe to heat recycling between fresh air and return air of the air conditioning system. In the test process, the fresh air inlet temperature is controlled within $32-40^{\circ} \mathrm{C}$ while the return air inlet temperature is unchanged, about $26^{\circ} \mathrm{C}$

Martinez have designed one kind of hybrid energy recycling system consisting of two conventional heat pipes and indirect evaporative heat exchanger. The hybrid energy representation system and the experimental design technology proceed at the same time. One important conclusion is used for installation of hybrid energy recycling system consisting of two conventional heat pipes 
and indirect evaporating heater of the air conditioner which can recycle part of the return air heat so as to improve the energy efficiency and reduce the impact on environment.

Tab.1. Geometrical characteristics of CHP, TPCT and OHP.

\begin{tabular}{|c|c|c|c|c|c|c|}
\hline & Heat Pipe & Qty. & $\begin{array}{c}\text { Working } \\
\text { Fluid/Filling } \\
\text { Factor } \\
\end{array}$ & Fin & Wick & Author \\
\hline CHP & $\begin{array}{c}\text { Material: copper } \\
\text { OD }: 15 \mathrm{~mm} \\
W_{\mathrm{t}}: 3 \mathrm{~mm} \\
L_{\mathrm{e}}: 300 \mathrm{~mm}, L_{\mathrm{t}}: 600 \mathrm{~mm}, \\
L_{\mathrm{c}}: 300 \mathrm{~mm}\end{array}$ & 8 & $\begin{array}{l}\text { Material: } \\
\text { methanol }\end{array}$ & None & $\begin{array}{l}100 \text { hole } \\
\text { Stainless } \\
\text { steel }\end{array}$ & $\mid \begin{array}{c}\text { Noie-Baghban } \\
\text { and Majideian } \\
{[2]}\end{array}$ \\
\hline CHP & $\begin{array}{c}O D: 12.7 \mathrm{~mm} \\
W_{\mathrm{t}}: 50 \mathrm{~cm} \\
L_{\mathrm{e}}: 20 \mathrm{~cm}, L_{\mathrm{a}}: 10 \mathrm{~cm}, \\
L_{\mathrm{c}}: 20 \mathrm{~cm}\end{array}$ & 25 & $\begin{array}{l}\text { Material: } \\
\text { R11, R123 }\end{array}$ & $\begin{array}{l}\text { Type: continuous fin } \\
\text { Material: aluminum } \\
\text { Thickness: } 0.5 \mathrm{~mm}\end{array}$ & $\begin{array}{l}100 \text { hole } \\
\text { Brass }\end{array}$ & $\begin{array}{c}\text { Abd El-Baky } \\
\text { and Mohamed } \\
{[3]}\end{array}$ \\
\hline CHP & $\begin{array}{c}\text { Material: } \\
O D: 12.7 \mathrm{~mm} \\
W_{\mathrm{t}}: 2.1 \mathrm{~mm} \\
L_{\mathrm{t}}: 62 \mathrm{~cm} \\
\end{array}$ & 12 & $\begin{array}{l}\text { Material: } \\
3.04 \mathrm{~g} \\
\text { ammonia }\end{array}$ & None & $\begin{array}{l}350 \text { hole } \\
\text { Stainless } \\
\text { steel }\end{array}$ & $\begin{array}{c}\text { Martinez et al. } \\
{[4]}\end{array}$ \\
\hline $\begin{array}{l}\text { Category } \\
1 \text { TPCT }\end{array}$ & $\begin{array}{c}\text { Material: copper } \\
\text { OD:15.88mm } \\
W_{\mathrm{t}}: 1.22 \mathrm{~mm} \\
L_{\mathrm{e}}: 300 \mathrm{~mm}, L_{\mathrm{a}}: 150 \mathrm{~mm} \text {, } \\
L_{\mathrm{c}}: 300 \mathrm{~mm}\end{array}$ & 24 & $\begin{array}{l}\text { Material: } \\
\text { water } \\
\text { Filling rate: } \\
\text { evaporation } \\
\text { section } 60 \%\end{array}$ & \begin{tabular}{|} 
Type: continuous fin \\
Material: copper \\
(evaporation section), \\
aluminum \\
(condensation section) \\
Interval: 472 pieces \\
each meter \\
Thickness: $0.162 \mathrm{~mm}$ \\
\end{tabular} & None & $\begin{array}{c}\text { Lukitobudi et } \\
\text { al. [5] }\end{array}$ \\
\hline $\begin{array}{l}\text { Category } \\
2 \text { TPCT }\end{array}$ & $\begin{array}{c}\text { Material: steel } \\
O D: 26.27 \mathrm{~mm} \\
W_{\mathrm{t}}: 7.65 \mathrm{~mm} \\
L_{\mathrm{e}}: 300 \mathrm{~mm}, L_{\mathrm{a}}: 150 \mathrm{~mm}, \\
L_{\mathrm{c}}: 300 \mathrm{~mm}\end{array}$ & 10 & $\begin{array}{c}\text { Material: } \\
\text { water } \\
\text { Filling rate: } \\
\text { evaporation } \\
\text { section } 60 \%\end{array}$ & $\begin{array}{c}\text { Type: spiral fin } \\
\text { Material: steel } \\
\text { Interval: } 472 \text { pieces } \\
\text { each meter } \\
\text { Thickness: } 0.8 \mathrm{~mm} \\
\text { Diameter: } 52.7 \mathrm{~mm}\end{array}$ & None & \\
\hline $\begin{array}{l}\text { Category } \\
3 \text { TPCT }\end{array}$ & $\begin{array}{c}\text { Material: copper } \\
O D: 15.88 \mathrm{~mm} \\
W_{\mathrm{t}}: 1.22 \mathrm{~mm} \\
L_{\mathrm{e}}: 300 \mathrm{~mm}, L_{\mathrm{a}}: 150 \mathrm{~mm}, \\
L_{\mathrm{c}}: 300 \mathrm{~mm}\end{array}$ & 24 & $\begin{array}{c}\text { Material: } \\
\text { water } \\
60 \% \\
\text { Filling rate: } \\
\text { evaporation } \\
\text { section } 60 \%\end{array}$ & None & None & \\
\hline TPCT & $\begin{array}{c}\text { Material: steel } \\
O D: 20 \mathrm{~mm} \\
W_{\mathrm{t}}: 1.5 \mathrm{~mm} \\
L_{\mathrm{e}}: 150 \mathrm{~mm}, L_{\mathrm{a}}: 5 \mathrm{~mm}, \\
L_{\mathrm{c}}: 150 \mathrm{~mm}\end{array}$ & 50 & $\begin{array}{l}\text { Material: } \\
\text { water } \\
\text { Filling rate: } \\
\text { evaporation } \\
\text { section 35\% }\end{array}$ & $\begin{array}{c}\text { Type: plate fin } \\
\text { Material: steel } \\
\text { Interval: } 315 \text { pieces } \\
\text { each meter } \\
\text { Thickness: } 1.5 \mathrm{~mm} \\
\text { Height: } 8 \mathrm{~mm}\end{array}$ & None & Yang et al. [6] \\
\hline $\begin{array}{l}\text { Category } \\
1 \text { TPCT }\end{array}$ & $\begin{array}{c}\text { Material: copper } \\
O D: 0.127 \mathrm{~m} \\
W_{\mathrm{t}}: 1.5 \mathrm{~mm} \\
L_{\mathrm{t}}: 0.45 \mathrm{~m}\end{array}$ & 7 & $\begin{array}{c}\text { Material: } \\
\text { methanol } \\
\text { Filling rate: } \\
\quad-\end{array}$ & \begin{tabular}{|c|} 
Type: plate fin \\
Material: copper \\
Qty: 70 pieces in total \\
Thickness: $0.45 \mathrm{~mm}$ \\
Height: $0.048 \mathrm{~m}$ \\
\end{tabular} & None & $\begin{array}{c}\text { Riffat and Gan } \\
\text { [7] }\end{array}$ \\
\hline
\end{tabular}




\begin{tabular}{|c|c|c|c|c|c|c|}
\hline & Heat Pipe & Qty. & \begin{tabular}{|c|} 
Working \\
Fluid/Filling \\
Factor \\
\end{tabular} & Fin & Wick & Author \\
\hline $\begin{array}{l}\text { Category } \\
2 \text { TPCT }\end{array}$ & $\begin{array}{c}\text { Material: copper } \\
O D: 0.127 \mathrm{~m} \\
W_{\mathrm{t}}: 1.5 \mathrm{~mm} \\
L_{\mathrm{t}}: 0.45 \mathrm{~m}\end{array}$ & 3 & $\begin{array}{c}\text { Material: } \\
\text { methanol } \\
\text { Filling rate: } \\
\quad-\end{array}$ & $\begin{array}{c}\text { Type: column type fin } \\
\text { Material: copper } \\
\text { Qty.: } 300 \text { pieces in } \\
\text { total } \\
\text { Thickness: } 0.45 \mathrm{~mm} \\
\text { Diameter: } 0.7 \mathrm{~mm}\end{array}$ & None & \\
\hline $\begin{array}{l}\text { Category } \\
3 \text { TPCT }\end{array}$ & $\begin{array}{c}\text { Material: copper } \\
I D: 18 \mathrm{~mm} \\
L_{\mathrm{t}}: 365 \mathrm{~m}\end{array}$ & 6 & $\begin{array}{c}\text { Material: } \\
\text { methanol } \\
\text { Filling rate: } \\
-\end{array}$ & \begin{tabular}{|c|} 
Type: shutter fin \\
Material: aluminum \\
Qty.: 96 pieces in total \\
Interval: $2 \mathrm{~mm}$ \\
Height: $60 \mathrm{~mm}$ \\
\end{tabular} & & \\
\hline ТРCT & $\begin{array}{c}\text { Material: copper } \\
I D: 15 \mathrm{~mm} \\
L_{\mathrm{t}}: 660 \mathrm{~mm}, L_{\mathrm{e}}: 300 \mathrm{~mm}, \\
L_{\mathrm{c}}: 300 \mathrm{~mm}\end{array}$ & 24 & $\begin{array}{c}\text { Material: } \\
\text { R22 } \\
\text { Filling rate: } \\
\text { evaporation } \\
\text { section } 60 \%\end{array}$ & \begin{tabular}{|c|} 
Type: plate fin \\
Material: aluminum \\
Interval: 32 pieces \\
each meter \\
Thickness: $0.164 \mathrm{~mm}$ \\
Height: $140 \mathrm{~mm}$ \\
\end{tabular} & & Wu et al. [8] \\
\hline СEОНР & $\begin{array}{c}I D: 2 \mathrm{~mm} \\
L_{\mathrm{e}}: 190 \mathrm{~mm}, L_{\mathrm{c}}: 190 \mathrm{~mm} \\
L_{\mathrm{t}}: 600 \mathrm{~mm}\end{array}$ & 1 & \begin{tabular}{|c|} 
Material: \\
water \\
Filling rate: \\
evaporation \\
section $50 \%$ \\
\end{tabular} & - & & $\begin{array}{c}\text { Rittidech et al. } \\
\text { [9] }\end{array}$ \\
\hline $\begin{array}{c}\text { CLOHP/ } \\
\text { CVs }\end{array}$ & $\begin{array}{c}I D: 2 \mathrm{~mm} \\
L_{\mathrm{e}}: 190 \mathrm{~mm}, L_{\mathrm{a}}: 8 \mathrm{~mm} \\
L_{\mathrm{c}}: 190 \mathrm{~mm}, L_{\mathrm{t}}: 358 \mathrm{~mm}\end{array}$ & 1 & \begin{tabular}{|c|} 
Material: \\
R134a \\
Filling rate: \\
evaporation \\
section $50 \%$
\end{tabular} & - & & $\begin{array}{l}\text { Meena et al. } \\
\text { [10] }\end{array}$ \\
\hline
\end{tabular}

In terms of two-phase closed thermosyphon application, Lukitobudi et al. [5] have designed, manufactured and tested one medium temperature two-phase closed thermosyphon heat exchanger for bakery. This heat exchanger is very efficient (65\%), but the author states that the overload pressure during operation may damage the heat exchanger. Yang et al. [6] have studied one possible two-phase closed thermosyphon exchanger to recycle the waste heat produced by large coach engine to provide heat for passengers. Riffat and Gan [7] have discussed the efficiency of two-phase closed thermosyphon heat exchanger in natural ventilated building. In their study, they have tested three kinds of heat recycling parts of two-phase closed thermosyphon exchanger. The first kind of exchanger consists of seven-pair fin heat pipe, the second kind of exchanger has spiral fin and the third kind consists of two rows of staggered two-phase closed thermosyphons. Thermodynamic simulation is used to solve the pressure loss characteristics of the parts. According to the experiment results, the efficiency of two-phase closed thermosyphon recycling parts is obviously affected by the air flow rate. As for the same speed, the exchanger efficiency is between $16 \%$ and $17 \%$ and the efficiency can be improved when the fins are increased from one row to two rows. According to the results of thermodynamic simulation, when the speed is $1 \mathrm{~m} / \mathrm{s}$, the predicated pressure loss of two rows of six heat pipes installed in parallel is 3.3 while that with staggering installation is 4.2 and that with seven small plates is 3.7. It is proposed by the study that as for the natural ventilated bottom building, the average design value of wind speed shall be less than $1 \mathrm{~m} / \mathrm{s}$ after the wind influence is removed. Wu et al. [6] have studied the humidity control of two-phase closed thermosyphon heat exchanger in air conditioning system. This type of heat exchanger has great advantages for replacing the conventional reheater, i.e. the energy can be saved and the cooling ability of cooling coil can be enhanced only with small amount of external energy or even no 
external energy.

\section{Conclusions}

The application of heat pipe exchanger for heat recycling is introduced in this paper. The heat pipe includes one efficient gas-gas heat recycling device, which reduces the business and industrial heat loss and guarantees the energy saving and environmental protection. It does not need external energy, cooling water or lubrication system. Since there is almost no cross leakage between waste gas and gas supply, it becomes the best choice. Heat pipe exchanger is characterized with many advantages, like high heat exchange efficiency, compact structure, no movable part, light weight, relatively economical, small pressure drop at the air side, completely separation of the thermal fluid and cold fluid, safe and reliable. In order to support future study and increase the thermal performance, following suggestions are put forward:

(1) Change the surface or diameter of the heat pipe;

(2) Increase the stay time of the fluid in the evaporation section and the condensation section;

(3) Increase proper pipeline so that the fluid can move freely between the evaporation section and the condensation section;

(4) Consider the type, mass, volume filling rate of the working fluid;

(5) Make the working fluid blister rapidly;

(6) Make the working fluid move towards one direction in the closed-loop OHP.

\section{References}

[1] Kim T H, Kim E A. A Study About Improvement of Efficiency of a Sewage Heat Utilization System (2nd Report: An analysis of efficiency of a sewage heat utilization system):(2nd Report : An analysis of efficiency of a sewage heat utilization system)[J]. Trans Jsrae, 2007, 24:101-107.

[2] Zhang J, Wang M L. Lanzhou City Sewage Heat Utilization Measurement Analysis[J]. Advanced Materials Research, 2012, 594-597:2095-2098.

[3] Kobayakawa T, Hihara E, Hanazaki H. A Study About Improvement of Efficiency of a Sewage Heat Utilization System[J]. Transactions of the Japan Society of Refrigerating \& Air Conditioning Engineers, 2012, 24:89-100.

[4] Yao Y, Zhao L Y, Ma Z L, et al. Simulation and analysis of a sewage-source heat pump in one medicine factory[J]. Journal of Harbin Institute of Technology, 2006, 38(5):797-800.

[5] Shen C, Jiang Y Q, Yao Y. Model and Algorithm for Simulation of a Novel Dry-Type Shell-Tube Evaporator Used in Sewage Source Heat Pump[C]// International Conference on Computer Distributed Control and Intelligent Environmental Monitoring. IEEE, 2011:446-449. 